\title{
Characterization of Tachykinin Receptors in Urinary Bladder from Guinea Pig
}

\author{
Michiko SHINKAI and Issei TAKAYANAGI* \\ Department of Chemical Pharmacology, Toho University School \\ of Pharmaceutical Sciences. Funabashi, Chiba 274, Japan
}

Accepted July 10, 1990

\begin{abstract}
The contractile responses to substance $P$ (SP), neurokinin $A$ (NKA), Tyr ${ }^{\circ}$-neurokinin $B$ (Tyr-NKB), senktide (NK3 receptor selective agonist) and $S P$ methyl ester (SPOMe. NK1 receptor selective agonist) were investigated in detrusor strips from guinea pigs. Except for senktide, all drugs induced a concentrationrelated contraction with the following rank order of potency: $S P O M e>S P>N K A \geqq$ Tyr-NKB. After desensitization of NK1 receptors with SPOMe, the rank order of potency was NKA $\geqq$ Tyr-NKB $>S P>S P O M e$. Both NK1 and NK2 receptors exist in the detrusor strip from guinea pigs.
\end{abstract}

In recent years, evidence has been presented that at least three distinct receptors for SP and related tachykinins (TKS) exist in mammalian tissues. Using the three established natural mammalian NKs, three distinct patterns of activity were identified showing the following rank order of potency at the three receptor sites: $S P>N K A>N K B$ on NK1 receptors, NKA $>N K B>S P$ on NK2 receptors and $N K B>N K A>S P$ on NK3 receptors.

SP-like immunoreactivity and immunoreactive nerves have been identified throughout the bladder $(1,2)$. SP causes contraction of guinea pig bladder $(3,4)$ and consequently, the possibility of SP-ergic neurotransmission in the bladder has recently been debated (5-7). Furthermore, in guinea pig bladder tachykinin(s) from capsaisin-insensitive sites is involved in the excitatory sympathomimetic effect of nicotine. and the tachykinin(s) behaves as a modulator finally to increase acetylcholine output from parasympathetic cholinergic nerves (8): subtypes of tachykinin receptors were not clarified.

In this study, the involvement of NK1 and NK2 receptors in tachykinin-induced contractions was investigated using the recently described selective agonist senktide (selective agonist for NK3 receptors (9)) and substance

\footnotetext{
* To whom reprints requests should be addressed.
}

P methyl ester (for NK1 receptors (10)).

The urinary bladder was removed from female Hartley strain guinea pigs $(300-500$ g) and a longitudinal strip ( $2 \mathrm{~mm} \times 20 \mathrm{~mm}$ ) of the detrusor muscle was prepared. Each strip was vertically suspended under a resting load of $1 \mathrm{~g}$ in a $10-\mathrm{ml}$ organ bath that contained Krebs solution of the following composition: $118 \mathrm{mM} \mathrm{NaCl}, 4.75 \mathrm{mM} \mathrm{KCl}$. $2.50 \mathrm{mM} \mathrm{CaCl}_{2}, 1.20 \mathrm{mM} \mathrm{MgSO}_{4}, 1.20 \mathrm{mM}$ $\mathrm{KH}_{2} \mathrm{PO}_{4}, 25.0 \mathrm{mM} \mathrm{NaHCO}$, and $10.0 \mathrm{mM}$ glucose. This was kept at $37^{\circ} \mathrm{C}$ and bubbled with $95 \% \mathrm{O}_{2}+5 \% \quad \mathrm{CO}_{2}$. The responses to drugs were recorded isotonically.

The experiments were started after the preparation had been allowed to equilibrate for $60 \mathrm{~min}$. After priming twice or 3 times with $300 \mathrm{nM}$ carbachol chloride (Sigma Chemical Co.), the control concentration curve for SP or SPOMe. NKA. Tyr-NKB. senktide (all from Peninsula Laboratories, Inc.) was determined. For desensitization of NK1 receptors, the preparation was treated with SPOMe at $1 / \mu \mathrm{M}$ until the response had faded to the baseline level. Then the tissue was washed and immediately reincubated with SPOMe at $1 \mu \mathrm{M}$. After 2-3 applications, the excitatory responses were completely abolished, and the concentration-response curve for peptides was again determined.

The $\mathrm{pD}_{2}$ values (the negative logarithm 
of the molar concentration necessary to produce a $50 \%$ response) of tachykinins before and after treatment with SPOMe at $1 \mu M$ are summarized in Table 1 . Senktide ( up to $3 \mu \mathrm{M}$ ) did not cause a contraction in guinea pig bladder, although this drug produced a contraction at a $\mathrm{nM}$ order of concentration in guinea pig ileum (data not shown). Other peptides exerted contractions in a concentration-dependent manner, and the rank order of potency was SPOMe> $S P>N K A \geqq T y r-N K B$. After the treatment with SPOMe described above, the $\mathrm{pD}_{2}$ value of SP was reduced $(7.01 \pm 0.04, n=6$ to $6.00 \pm 0.03, n=6$. Table 1), and the rank order of potency was NKA $\geqq T y r-N K B>$ $\mathrm{SP}>\mathrm{SPOMe}$.

Growcott et al. (11) suggested the existence of at least two different receptor subtypes for the tachykinins in guinea pig bladder because the sensitivity of eledoisin to phenoxybenzamine was different from that to physalaemine. Furthermore, Hunter and Maggio (4) suggested that the guinea pig bladder contains two different tachykinin receptors, since the $p K_{B}$ value (a negative logarithm of a dissociation constant) of antagonist ([D-Arg ${ }^{1}, \quad$ D-Pro ${ }^{2}, \quad$ D-Trp ${ }^{7,9}$, Leu11]-SP) against NKA was significantly higher than its $\mathrm{pK}_{B}$ value against SP. Recent studies by mechanical responses and radioligand binding assays have suggested the existence of three tachykinin receptor subtypes, called NK1. NK2 and NK3. Therefore. in the present study using the recently described two selective agonists, senktide (for NK3 (9)) and SPOMe (for SP-P later renamed NK1 (10)), we confirmed that both NK1 and NK2 subtypes exist in detrusor strips from guinea pig.

The NK-3-selective agonist senktide (up to $3 \mu \mathrm{M}$ ) did not cause a contraction but produced a contraction at $\mathrm{nM}$ order in guinea pig ileum, indicating the drug's effectiveness. The results thus suggest that few NK3 receptors exist in this preparation and that they do not play an important role in the tachykinin-induced contraction.

SPOMe was the most potent agonist followed by $S P>N K A \geqq T y r-N K B$, indicating that a NK1 receptor subtype was present in guinea pig bladder. With successive application of SPOMe at $1 \mu \mathrm{M}$. desensitization of the drug-induced contraction was achieved, and under this condition, NK1 receptors were inactivated. After SPOMetreatment, the $\mathrm{pD}_{2}$ value of $\mathrm{SP}$ was lower than the value before SPOMe-treatment. The rank order of potency was changed to the following: NKA $\geqq T y r-N K B>S P>$ SPOMe. Therefore, desensitization of NK1 receptors revealed the existence of NK2 receptors in this preparation.

These results indicate that both NK1 and NK2 receptors exist guinea pig urinary bladder. Tachykinin receptors are thought to be present not only in the smooth muscle but in the neuronal sites. Activation of NK3 receptors on enteric neurons results in acetylcholine and tachykinin release in the guinea pig ileum (12). Furthermore, it seems that the cholinergic neurons in the guinea pig urinary bladder are regulated by tachykinin(s) (8, 13). Hisayama et al. (1989) suggested that tachykinin(s) behave(s) as a modulator finally to increase the acetylcholine release from the parasympathetic cholinergic nerve. It is considered from the

Table 1. The $\mathrm{pD}_{2}$ value of tachykinins before and after the treatment with SPOMe at $1 \mu \mathrm{M}$

\begin{tabular}{lcc}
\hline & SPOMe $(-)$ & $\mathrm{pD}_{2}$ values \\
Neurokinin A & $6.41 \pm 0.07(6)$ & SPOMe $(+)$ \\
Tyr ${ }^{\circ}$-neurokinin B & $6.35 \pm 0.10(6)$ & $6.53 \pm 0.06(6)$ \\
Substance P & $7.01 \pm 0.04(6)$ & $6.17 \pm 0.07(6)$ \\
SPOMe & $7.43 \pm 0.13(6)$ & $6.00 \pm 0.03(6)^{*}$ \\
\hline
\end{tabular}

Note that after SPOMe-treatment, the $\mathrm{pD}_{2}$ value of SP was lower that the value before SPOMe-treatment. Values are presented as means with S.E. and the number of experiments is shown in parentheses. SPOMe $(-)$ or $(+)$ : before and after the treatment with SPOMe at $1 \mu \mathrm{M}$. *: Significant difference from the corresponding value in the absence of SPOMe at $1 / 2 \mathrm{M}$. SPOMe: substance P methyl ester. 
present results that NK1 and/or NK2 receptors are related to the acetylcholine release in this preparation, although further studies are needed to identify the sites of action of these tachykinins.

Acknowledgments: This research was supported by a Grant-in-Aid (No. 02771724) for Scientific Research from the Ministry of Education, Science and Culture, Japan, and supported in part by grants from Teijin Co., Ltd. (Japan).

\section{References}

1 Alm, P., Alumets, J., Brodin, E., Håkanson, R., Nilsson, G., Sjoberg, N.-O. and Sundler, F.: Peptidergic (substance $P$ ) nerves in the genitourinary tract. Neuroscience 3, 419-425 (1978)

2 Hokfelt, T., Schultzberg, M., Elde, R., Nilsson, G., Terenius, L., Said, S, and Goldstein, M.: Peptide neurons in peripheral tissues including the urinary tract: immunohistochemical studies. Acta Pharmacol. Toxicol. 43, Supp. 79-89 (1978)

3 Falconieri Erspamer, G., Erspamer, V. and Piccinelli, D.: Parallel bioassay of physalaemine and kassinin, a tachykinin dodecapeptide from the skin of the African frog Kassina Senegalensis. Naunyn Schmiedebergs Arch. Pharmacol. 331. 61-65 (1980)

4 Hunter, J.C. and Maggio, J.E.: A pharmacological study with substance $K$ : evidence for multiple types of tachykinin receptors. Eur. J. Pharmacol. 105, 149-153 (1984)

5 MacKenzie, 1. and Burnstock, G.: Neuropeptide action on the guinea-pig bladder: a comparison with the effects of field stimulation and ATP. Eur. J. Pharmacol. 105, 85-94 (1984)

6 Hourani, S.M.O.: Desensitization of the guinea- pig urinary bladder by the enantiomers of adenylyl $5^{\prime}-(\beta, \gamma$-methylene $)$-diphosphate and by substance $\mathrm{P}$. Br. J. Pharmacol. 82, 161-164 (1978)

7 Callahan, S.M. and Creed, K.E.: Non-cholinergic neurotransmission and the effect of peptides on the urinary bladder of guinea-pig and rabbits. J. Physiol. (Lond.) 374, 103-115 (1986)

8 Hisayama, T., Shinkai, M., Takayanagi, I. and Toyoda, T.: Mechanism of action of nicotine in isolated urinary bladder of guinea-pig: Involvement of tachykinin(s) released by nicotine in the drug's sympathomimetic effect. Arch. Int. Pharmacodyn. Ther. 301, 277-284 (1989)

9 Warmser, U., Laufer, R., Chorev, M., Gilon, C. and Selinger, Z.: Highly selective agonists for substance $P$ receptor subtypes. EMBO J. 5, 2805-2808 (1986)

10 Watson, S.P., Sandberg, B.E.B., Hanley, M.R. and Iversen, L.L.: Tissue selectivity of substance $P$ alkyl esters: Suggesting multiple receptors. Eur. J. Pharmacol. 87, 77-84 (1983)

11 Growcott, J.W., Jamieson, A., Anne, V.T. and Topham, L.D.: Further evidence for multiple tachykinin receptors. Eur. J. Pharmacol. 86, 5964 (1983)

12 Guard, S. and Watson, S.P.: Evidence for neurokinin-3 receptor-mediated tachykinin release in the guinea-pig ileum. Eur. J. Pharmacol. 144, 409-412 (1987)

13 Shirakawa, J., Nakanishi, T., Taniyama, K., Kamidono, S. and Tanaka, C.: Regulation of the substance $\mathrm{P}$-induced contraction via the release of acetylcholine and $\gamma$-aminobutyric acid in the guinea-pig urinary bladder. Br. J. Pharmacol. 98, 437-444 (1989) 